\title{
Pengaruh Efektivitas Sistem Informasi Akuntansi pada Kinerja Karyawan dengan Insentif dan Motivasi Kerja sebagai Pemoderasi
}

\author{
Chandrika Hutami Prariadena ${ }^{1}$ \\ I Made Pande Dwiana Putra ${ }^{2}$
}

\author{
${ }^{1,2}$ Fakultas Ekonomi dan Bisnis Universitas Udayana (Unud), Bali, Indonesia \\ e-mail: chandrikahutami@gmail.com
}

\begin{abstract}
ABSTRAK
Penelitian ini bertujuan untuk mencari tahu bagaimana pengaruh efektivitas system informasi akuntansi terhadap kinerja karyawan dengan insentif dan motivasi kerja sebagai pemoderasi di LPD Kota Denpasar. Populasi penelitian ini adalah karyawan di 35 LPD di Kota Denpasar. Metode purposive sampling digunakan untuk menentukan sampel dan didapatkan sampel sejumlah 99 orang. Metode pengumpulan data dilakukan dengan menggunakan metode kuesioner dan teknik analisis data regresi linear sederhana dan analisis regresi moderasi. Berdasarkan hasil analisis ditemukan bahwa sistem informasi akuntansi berpengaruh positif pada kinerja karyawan, insentif memperlemah pengaruh efektivitas sistem informasi akuntansi pada kinerja karyawan, dan motivasi kerja memperkuat pengaruh efektivitas system informasi akuntansi pada kinerja karyawan di LPD Kota Denpasar.

Kata Kunci : Efektivitas sistem informasi akuntansi, insentif, motivasi kerja, kinerja karyawan
\end{abstract}

\begin{abstract}
This study aims to determine the effect of the effectiveness of accounting information systems on employees' performance with incentives and work motivation as moderators in Denpasar LPD. The population of this study was employees at the 35 LPDs in Denpasar. The sample was determined by using a purposive sampling method with a total sample of 99 people. The methods of data collection were done by using questionnaire method and simple linear regression data analysis techniques and moderation regression analysis. Based on the results of the analysis found that the effectiveness of accounting information systems have positive effects on employees' performance such as incentives weaken the effectiveness of accounting information systems on employee performance and work motivation reinforces the effectiveness of accounting information systems on employee performance in Denpasar LPD.

Keywords : Effectiveness of accounting information systems, incentives, work motivation employee performance.
\end{abstract}

\section{PENDAHULUAN}

Desa pakraman atau yang biasa disebut dengan desa adat di Bali adalah sekelompok masyarakat yang memiliki landasan hukum adat di Provinsi Bali serta mempunyai tradisi dan tata krama dalam hal keagamaan dan sosial kemasyarakatan. LPD atau Lembaga Perkreditan Desa merupakan hasil dari tuntutan Desa pakraman untuk memiliki tata kelola perekonomiannya sendiri. 
LPD merupakan lembaga keuangan yang ada milik desa pakraman untuk mengelola uang dari masyarakat desa setempat yang bertujuan untuk mendorong pembangunan ekonomi masyarakat dan diharapkan dapat membantu masyarakat dengan mempermudah pemberian pinjaman dana dalam bentuk kredit.

LPD yang ada di Kota Denpasar sudah melaksanakan perannya dalam menyalurkan kredit, dapat dilihat pada Tabel 1 yang menmperlihatkan jumlah dari kredit serta pertumbuhannya pada tahun 2013-2017.

Tabel 1.

Perkembangan Kredit LPD di Kota Denpasar Tahun 2013-2017

\begin{tabular}{crr}
\hline Tahun & $\begin{array}{r}\text { Total Kredit } \\
\text { (dalam ribuan rupiah) }\end{array}$ & $\begin{array}{r}\text { Pertumbuhan Kredit } \\
\text { (dalam persen) }\end{array}$ \\
\hline 2013 & $775,006,137$ & 29,56 \\
2014 & $933,462,026$ & 20,45 \\
2015 & $1,109,998,494$ & 18,91 \\
2016 & $1,244,928,476$ & 12,16 \\
2017 & $1,361,180,790$ & 9,34 \\
Rata-rata & $1,084,915,185$ & 18,08 \\
\hline
\end{tabular}

Sumber : Lembaga Pemberdayaan LPD Kota Denpasar, 2018

Tabel 1 memperlihatkan bahwa LPD di Kota Denpasar memiliki rata-rata kredit sebesar $\mathrm{Rp} 1,08$ triliun serta memiliki rata-rata pertumbuhan kredit 18,08 persen. Pertumbuhan dari persentase kredit yang terjadi dari tahun 2013-2017 pada LPD di Kota Denpasar memperlihatkan adanya pertumbuhan yang cenderung menurun. Berdasarkan data yang diperoleh dari LPLPD (Lembaga Pemberdayaan Lembaga Perkreditan Desa) Kota Denpasar, dari 35 LPD yang ada di Kota Denpasar hanya 30 LPD yang dinyatakan sehat dan 5 LPD dinyatakan kurang sehat, hal ini dapat disebabkan oleh pertumbuhan kredit di LPD Kota Denpasar.

Permasalahan lainnya yang terjadi di LPD yaitu adalah permasalahan internal seperti menurut artikel yang dikutip pada BeritaBali (2016) Rai Mantra 
menyampaikan bahwa setiap terjadi permasalahan pada LPD di Kota Denpasar disebabkan karena adanya masalah dari dalam atau internal di kepengurusan LPD itu sendiri. Dibuktikan pada fenomena yang terjadi pada LPD Serangan yang pada tahun 2014 dikatakan macet dan tidak beroperasi sebagaimana mestinya dikarenakan mantan Bendesa Adat Serangan yang berinisial MW diduga melakukan penggelapan dana sehingga mengakibatkan kerugian sekitar $\mathrm{Rp} 1$ miliar (Sandi, 2014).

Dalam suatu lembaga SDM (sumber daya manusia) memiliki suatu peranan penting didalam pencapaian sebuah target, hal ini dikarenakan apabila tidak adanya faktor perilaku manusia sistem yang sudah ada tidak akan berjalan dengan baik (Fatmayoni \& Yadnyana, 2017). Penggunaan sarana teknologi yang sudah ada adalah salah satu cara untuk mempermudah serta meningkatkan kinerja karyawan. Menurut penelitian Goodhue \& Thompson (1995) tentang model Technology to Performance Chain (TPC) penggunaan atau pemanfaat teknologi yang tepat diharapkan dapat meningkatkan kinerja individu secara khusus maupun kinerja organisasi secara umum.

Rai, et al (2002) menyatakan bahwa salah satu konsep yang dijadikan sebagai kriteria dasar untuk mengevaluasi sistem dan kualitas dari informasi yang dihasilkan adalah system informasi. Suatu system yang bekerja secara efektif akan mendapatkan hasil informasi yang memiliki kualitas serta dapat memudahkan kinerja penggunanya. Kualitas informasi akuntansi berperan penting untuk peningkatan efektivitas dan kepengurusan setiap organisasi hal ini dikarenakan informasi dan data menjadi dasar atas kegiatan usaha individu (Nwokeji, 2012). 
Apabila sumber daya manusia dalam penggunaan teknologi informasi efektif, maka dapat menghasilkan informasi-informasi yang efektif.

Sistem informasi akuntasi dapat membantu meningkatkan efektivitas seorang karyawan dalam bekerja di suatu perusahaan. LPD di Kota Denpasar sudah menerapkan sistem informasi akuntansi yang berbasis komputer dalam pengolahan datanya dikarenakan tingginya jumlah aset yang dimiliki. Data yang didapat dari LPLPD Kota Denpasar menunjukkan bahwa pada tahun 2017 aset yang dimiliki LPD Kota Denpasar mencapai Rp 1,9 triliun dan mengalami kenaikan dari tahun 2016 sebesar Rp 1,6 triliun.

Penelitian ini ingin menguji pengaruh variabel efektivitas sistem informasi akuntansi terhadap variabel kinerja karyawan yang pada penelitian sebelumnya masih ditemukanya ketidakkonsistenan. Penelitian yang dilakukan oleh Astuti \& Dharmadiaksa (2014) menunjukkan bahwa efektivitas penerapan system informasi akuntansi memberikan pengaruh yang positif dan signifikan terhadap kinerja karyawan pada koperasi simpan pinjam di Kabupaten Gianyar. Hasil penelitian ini sejalan dengan hasil penelitian dari Veriana \& Budiartha (2016) menunjukkan bahwa efektivitas sistem informasi akuntansi berpengaruh positif pada kinerja karyawan di LPD Kecamatan Mengwi. Mercika \& Jati (2015) menyatakan bahwa efektivitas system informasi akuntansi berpengaruh positif dan signifikan terhadap kinerja karyawan. Ariputra \& Suaryana (2018) menyatakan bahwa efektivitas penerapan SIA berpengaruh positif terhadap kinerja karyawan pada PT. PLN Distribusi Bali. 
Hasil penelitian yang dilakukan oleh Kharuddin, et al (2010), Urquia, et al (2011), dan Kouser, et al (2011) yang menunjukkan bahwa bahwa pengadopsian sistem informasi akuntansi tidak dapat meningkatkan kinerja, profitabilitas dan efeisiensi operasi. Soudani, (2012) juga menyatakan bahwa pemakaian sistem informasi akuntansi tidak memiliki pengaruh terhadap kinerja manajemen. Ketidakkonsistenan dari penelitian sebelumnya diduga disebabkan oleh adanya faktor kontingensi seperti insentif dan motivasi kerja.

Insentif merupakan salah satu faktor pendorong dalam peningkatan kinerja karyawan. Menurut Anggriawan, dkk (2015) insentif adalah suatu penghargaan yang diberikan kepada karyawan atas kinerja yang telah dilakukan dengan maksud agar karyawan tersebut memiliki semangat kerja yang tinggi agar mau bekerja dengan lebih baik dan bersungguh-sungguh untuk meningkatkan kinerja yang lebih tinggi. Pemberian insentif kepada karyawan merupakan salah satu sarana untuk mendorong para karyawan dalam bekerja dengan kemampuannya yang optimal, sebagai pendapatan tambahan diluar gaji yang telah ditentukan.

Motivasi adalah salah satu konsep psikologi yang paling penting dan vital bagi manajer dalam mengarahkan bawahannya untuk mendapatkan tujuan yang baik bagi perusahaan (Ali, Abrar, \& Haider, 2012). Motivasi dapat dipandang sebagai perubahan energi dalam diri seseorang yang ditandai dengan munculnya suatu perasaan dan didahului dengan suatu respon terhadap suatu tujuan (Mahardhika, dkk, 2013). Motivasi kerja merupakan satu aktor yang 
menentukan jalan tidaknya suatu pekerjaan dari visi dan misi yang dijabarkan dalam pencapaian tujuan organisasi secara keseluruhan.

Teori Technology-to-Performance Chain merupakan model penelitian yang dipelopori oleh Goodhue \& Thompson (1995) tentang pengaruh pemanfaatan teknologi informasi terhadap kinerja individual maupun perusahaan. Model rantai teknologi-ke-kinerja (technology-to-performance chain) dibangun dengan menggabungkan model pemakaian (utilization) dengan model kesesuaian (fit). Menyadari bahwa teknologi harus digunakan (utilized) terlebih dahulu dan sesuai (fit) dengan tugas yang didukung oleh teknologinya untuk mendapatkan dampak kinerja, model ini memberikan gambaran yang lebih akurat tentang teknologi, tugas-tugas pemakai dan pemakaian (utilization) yang saling berhubungan untuk mencapai kinerja.

Teori ekspektansi dikemukakan oleh Victor H. Vroom dalam Surbakti (2014). Menurut teori ekspektansi hal yang memotivasi seseorang untuk bekerja lebih giat dalam pekerjaannya tergantung dari apa yang sedang diinginkan dan dibutuhkan dari hasil pekerjaan yang dilakukan itu. Teori ekspektansi ini memiliki tiga variabel yaitu daya tarik, hubungan antara kinerja dengan imbalan, dan hubungan antara usaha dan kinerja.

Bodnar \& Hopwood (2006:3) menyatakan bahwa Sistem Informasi Akuntansi (SIA) merupakan kumpulan sumber daya, seperti manusia dan peralatan, yang dirancang untuk mengubah data keuangan dan data lainnya ke dalam informasi yang kemudian dikomunikasikan kepada para pengambil keputusan. Efektivitas adalah suatu ukuran mengenai seberapa baik pekerjaan 
yang dilakukan seseorang untuk dapat menghasilkan output yang sesuai dengan yang diharapkan (Kristiani, 2012).

Efektivitas sistem informasi akuntansi merupakan suatu ukuran untuk memberikan gambaran mengenai sejauh mana suatu sasaran dapat dicapai dari kumpulan sumber daya yang diatur untuk mengumpulkan, memproses, dan menyimpan data elektronik. Data tersebut kemudian diubah menjadi sebuah informasi yang menyediakan laporan formal yang dibutuhkan (Sugiartini \& Dharmadiaksa, 2016). Novita (2011) dalam Sugiartini \& Dharmadiaksa (2016) menyatakan bahwa sistem informasi dikatakan efektif apabila informasi yang dihasilkan oleh sistem tersebut dapat melayani kebutuhan dari pengguna sistem tersebut.

Menurut Verbeeten (2008) dalam Fatmayoni \& Yadnyana (2017) insentif merupakan penghargaan oleh perusahaan yang berbentuk material maupun non material yang diberikan oleh pihak pimpinan perusahaan untuk karyawannya yang bertujuan agar karyawan memiliki motivasi yang tinggi dalam bekerja dan memiliki prestasi dalam mencapai tujuan yang ditentukan oleh perusahaan, dengan kata lain insentif yang diberikan ialah pemberian uang diluar gaji sebagai reward yang diberikan oleh perusahaan terhadap prestasi kerja dan kontribusi oleh karyawan. Pemberian insentif dimaksudkan agar dapat memenuhi kebutuhan para karyawan dan keluarga mereka (Anggriawan et al., 2015).

Motivasi kerja merupakan salah satu aspek perilaku psikologis karyawan, dimana motivasi merupakan akibat dari interaksi karyawan dan situasi. Munculnya motivasi berasal dari dorongan dalam diri manusia karena adanya 
unsur suatu tujuan. Tujuan dalam melakukan pekerjaan pasti didasarkan soal kebutuhan hidup, dapat disimpulkan bahwa tidak akan ada motivasi dalam melakukan pekerjaan apabila tidak dirasakan adanya suatu kebutuhan (Mahardhika, et al., 2013). Manajer diharapkan dapat mengidentifikasi jenis kebutuhan yang dimiliki seseorang dan situasi dimana mereka akan termotivasi untuk memenuhi kebutuhannya dengan cara berkontribusi pada kinerja dan produktivitas Ghaffari, et al (2017).

Sebuah kinerja adalah perilaku nyata pegawai sebagai prestasi kerja yang dihasilkan sesuai dengan perannya dalam perusahaan atau organisasi. Ada beberapa faktor mengenai kinerja karyawan, antara lain faktor internal dan faktor eksternal yang mempengaruhi kinerja karyawan yang selanjutnya berpengaruh juga pada kinerja perusahaan atau organisasi (Widyastuti \& Hasan, 2015). Kinerja seseorang dikatakan baik apabila orang tersebut memiliki keahlian yang tinggi dalam bidangnya, bersedia untuk bekerja, dan memiliki imbalan yang layak akan mempunyai harapan di masa yang akan datang (Mercika \& Jati, 2015).

Technology-to-Performance Chain (TPC) merupakan sebuah teori yang menyatakan bahwa teknologi memiliki dampak yang positif pada kinerja individual hal ini disebabkan karena dengan adanya teknologi akan memudahkan tugas untuk menyelesaikan tugas setiap individu yang ada dan memiliki dampak pada kinerja yang dihasilkan. Sistem informasi akuntansi menjadi salah satu sarana penting bagi suatu perusahaan untuk meningkatkan kinerjanya (Al-Eqab \& Adel, 2013). Penelitian oleh Ariputra \& Suaryana (2018) menyimpulkan bahwa efektivitas penerapan SIA berpengaruh positif terhadap kinerja karyawan. Hal ini 
memiliki arti bahwa semakin tinggi tingkat efektivitas penerapan SIA menyebabkan peningkatan kinerja karyawan.

Mercika \& Jati (2015) juga mengatakan adanya pengaruh positif dan signifikan terhadap kinerja karyawan karena adanya efektivitas sistem informasi akuntansi. Sejalan dengan hal tersebut penelitian dari Veriana \& Budiartha (2016) menyatakan bahwa semakin tinggi kemampuan teknik pemakai sistem informasi akuntansi karyawan, maka kinerja karyawan akan meningkat. Gunawan \& Tenaya (2017) juga menyatakan bahwa efektivitas sistem informasi akuntansi memiliki pengaruh positif pada kinerja karyawan. Dari uraian di atas, maka didapatkan rumusan hipotesis sebagai berikut:

$\mathrm{H}_{1}$ : Efektivitas sistem informasi akuntansi berpengaruh positif pada kinerja karyawan.

Kinerja sebuah sistem informasi akan berjalan dengan baik apabila pemakai sistem dapat memahami dan menggunakannya menjadi sebuah informasi yang berguna dalam pengambilan keputusan, sehingga dapat terpenuhinya tujuan dari perusahaan tersebut dan kinerja karyawan dapat dinilai baik. Insentif merupakan sebuah sarana untuk mendorong seseorang atau karyawan agar dapat bekerja dengan lebih baik, Pada kondisi dimana penggunaan sistem informasi akuntansi yang efektif disertai dengan pemberian insentif karyawan yang tinggi maka kinerja karyawan tersebut juga akan menjadi lebih baik. Namun sebaliknya, efektivitas sistem informasi akuntansi tanpa disertai insentif yang memadai akan menghasilkan kinerja karyawan yang kurang optimal.

Penelitian dari Fatmayoni \& Yadnyana (2017) dan Suryawan \& Suaryana (2018) mengatakan bahwa meningkatnya insentif karyawan mampu memperkuat 
hubungan antara variabel efektivitas sistem informasi akuntansi terhadap kinerja individual. Hal tersebut dikarenakan semakin tinggi insentif akan meningkatkan pengaruh efektivitas sistem informasi terhadap kinerja individual. Berdasarkan uraian di atas, maka rumusan hipotesis yang digunakan dalam penelitian ini adalah.

$\mathrm{H}_{2}$ : Insentif memperkuat pengaruh efektivitas sistem informasi akuntansi terhadap kinerja karyawan.

Salah satu variabel penting yang memiliki pengaruh besar bagi organisasi untuk peningkatan kinerja karyawan adalah motivasi. Seorang pegawai atau karyawan yang sudah memiliki motivasi akan bertahan pada pekerjaannya dalam jangka waktu yang cukup lama sebagai langkah untuk mencapai tujuan mereka. Karyawan akan bertahan lama pada pekerjaannya ketika ia merasa telah bekerja secara efektif, suatu Sistem Informasi Akuntansi yang telah terkomputerisasi tentu sajalebih efektif bagi karyawan (Krisnawati \& Suartana, 2017).

Pada kondisi dimana penggunaan sistem informasi akuntansi yang efektif disertai dengan tingginya motivasi kerja suatu karyawan maka kinerja karyawan tersebut juga akan menjadi lebih baik. Namun sebaliknya, efektivitas sistem informasi akuntansi tanpa disertai dengan motivasi kerja yang tinggi akan menghasilkan kinerja karyawan yang kurang optimal. Tanpa adanya pemberian dorongan seperti sarana yang memadai dan penghargaan kepada karyawan, maka karyawan akan cenderung tidak bersemangat dalam bekerja terutama dalam menggunakan sistem informasi akuntansi, sehingga seefektif apapun sistem tersebut tidak akan terlalu berpengaruh pada kinerja karyawan. Berdasarkan 
uraian di atas, maka rumusan hipotesis yang digunakan dalam penelitian ini adalah:

$\mathrm{H}_{3}$ : Motivasi kerja memperkuat pengaruh efektivitas sistem informasi akuntansi terhadap kinerja karyawan.

\section{METODE PENELITIAN}

Penelitian ini dilakukan di Lembaga Perkreditan Desa (LPD) Kota Denpasar, yang ada di empat kecamatan Kota Denpasar. Obyek penelitian ini yaitu kinerja karyawan di LPD Kota Denpasar. Variabel bebas atau dependen dalam penelitian ini adalah Kinerja Karyawan (Y). Variabel terikat atau independen dalam penelitian ini adalah Efektivitas Sistem Informasi Akuntansi (X1). Variabel moderasi dalam penelitian ini adalah Insentif (X2) dan Motivasi Kerja (X3).

Ukuran variabel efektivitas sistem informasi akuntansi yang diadopsi dari peneltian Astuti \& Dharmadiaksa (2014), yaitu diukur dengan indikator pengukuran waktu, keamanan data, relevansi, keakuratan, dan variasi laporan. Mengadopsi dari penelitian Dwijayanthi \& Dharmadiaksa (2013), indikator pengukuran variabel insentif yang digunakan adalah insentif berupa uang tunai atau sertifikat, insentif yang diberikan sesuai dengan badan kerja, penghargaan atas prestasi yang dicapai, insentif yang diterima sudah memenuhi kebutuhan karyawan, dan insentif yang diterima dapat memicu kinerja. Indikator pengukuran variabel motivasi kerja dalam penelitian ini diadopsi dari instrumen yang dikembangkan oleh Simanjuntak (2012) dalam Dewi (2014) yang telah dimodifikasi, yaitu rasa aman dan nyaman dalam bekerja, penghargaan, kelengkapan peralatan kerja, semangat kerja, dan inisiatif dan kreatif. Indikator 
pengukuran variabel kinerja karyawan yang mengadopsi dari penelitian yang dilakukan Astuti \& Dharmadiaksa (2014), yaitu produktivitas, kualitas kerja, efektivitas, kuantitas kerja, dan pelayanan sistem komputer.

Populasi pada penelitian ini merupakan karyawan LPD di Kota Denpasar, dimana karyawannya telah menggunakan sistem yang terkomputerisasi sejumlah 527 orang. Sampel yang digunakan pada penelitian ini ialah karyawan LPD di Kota Denpasar yang dipilih mengunakan metode dalam penentuan sampel yaitu nonprobability sampling dengan teknik purposive sampling. Metode dalam pengumpulan data yang digunakan dalam penelitian ini adalah metode survey berupa kuesioner dan hasil jawaban kuesioner diukur dengan menggunakan skala likert 6 poin dimana skor 6 adalah poin tertinggi dan skor 1 adalah poin terendah.

Perhitungan analisis yang digunakan dalam penelitian ini adalah teknik Analisis Regresi Sederhana dan Moderated Regression Analysis (MRA). Analisis regresi sederhana digunakan untuk mengukur hubungan antara satu variabel bebas dengan satu variabel terikat. Persamaan analisis regresi linear sederhana pada penelitian ini sebagai berikut:

$$
\mathrm{Y}=\alpha+\beta_{1} \mathrm{X}_{1}+\varepsilon
$$

Keterangan:

$\mathrm{Y} \quad=$ Variabel dependen Kinerja Karyawan

$\mathrm{X}_{1}=$ Variabel independen Efektivitas Sistem Informasi Akuntansi

$\beta_{1} \quad=$ Koefisien regresi

$\alpha \quad=$ Konstanta

$\varepsilon \quad=$ Error

Uji interaksi adalah salah satu cara yang dapat digunakan untuk menguji apakah suatu variabel moderating. Moderated Regression Analysis (MRA) merupakan regresi dengan melakukan uji interaksi antarvariabel. MRA 
merupakan pengukuran khusus regresi linear berganda dimana dalam persamaan regresinya mengandung unsur interaksi (perkalian dua atau lebih variable independen). Persamaan Moderated Regression Analysis sebagai berikut:

$$
Y=a+\beta_{1} X_{1}+\beta_{2} X_{2}+\beta_{3} X_{3}+\beta_{4} X_{1} X_{2}+\beta_{5} X_{1} X_{3}+\varepsilon
$$

Keterangan:

$\mathrm{Y} \quad=$ Variabel dependen Kinerja karyawan

$\mathrm{X}_{1} \quad=$ Variabel independen Efektivitas sistem informasi akuntansi

$\mathrm{X}_{2} \quad=$ Variabel moderasi Insentif

$\mathrm{X}_{3} \quad=$ Variabel moderasi Motivasi kerja

$\mathrm{X}_{1} \mathrm{X}_{2}=$ Interaksi antara variable independen efektivitas system informasi akuntansi dengan variable moderasi insentif

$\mathrm{X}_{1} \mathrm{X}_{3}=$ Interaksi antara variabel independen efektivitas sistem informasi akuntansi dengan variabel moderasi motivasi kerja

a $\quad=$ Konstanta

$\beta_{1}-\beta_{5} \quad=$ Koefisien regresi

$\varepsilon \quad=$ Error

\section{HASIL DAN PEMBAHASAN}

Pengumpulan data dilakukan dengan menyebarkan kuesioner secara langsung ke masing-masing 35 LPD yang dilakukan selama 7 hari dari tanggal 9 November 2018 sampai tanggal 16 November 2018 dan peneliti mengumpulkan kembali dalam kurun waktu 9 hari yaitu dari tanggal 17 November 2018 sampai dengan tanggal 26 November 2018. Total kuesioner yang disebarkan sebanyak 102 kuesioner, kuesioner yang kembali sebanyak 99 kuesioner, kuesioner yang tidak kembali sebanyak 3 kuesioner dikarenakan kesibukan LPD. Berdasarkan kondisi tersebut hanya 99 kuesioner $(94,29$ persen) yang masuk dalam kriteria sampel untuk dapat diproses lebih lanjut. Rincian mengenai pengiriman dan pengembalian kuesioner dapat dilihat pada Tabel 2. 
Tabel 2.

Rincian Pengiriman dan Pengembalian Kuesioner

\begin{tabular}{lr}
\hline \multicolumn{1}{c}{ Keterangan } & Jumlah \\
\hline Kuesioner yang disebarkan & 102 \\
Kuesioner yang tidak kembali & $(3)$ \\
Kuesioner yang kembali & 99 \\
Kuesioner yang tidak dapat digunakan & $(0)$ \\
Kuesioner yang digunakan & 99 \\
Tingkat pengembalian yang digunakan (usable response rate) & \\
Kuesioneryang digunakan & \\
$\frac{\text { Kuesioner yang disebar }}{\text { Sumber : Data diolah, } 2018 \%}$ & $94,29 \%$ \\
\hline
\end{tabular}

Uji validitas dan uji reliabilitas adalah uji yang dapat dilakukan sebelum data dianalisis lebih lanjut. Kedua uji ini dilakukan dengan tujuan untuk meyakinkan bahwa item-item instrumen penelitian dapat dikatakan valid dan reliabel. Kuesioner dapat dikatakan valid jika nilai Pearson's correlation terhadap total skor lebih besar dari 0,3 . Seluruh indikator pernyataan dalam kuesioner pada penelitian ini dengan variable kinerja karyawan (Y), efektivitas sistem informasi akuntansi (X1), insentif (X2), dan motivasi kerja (X3) memiliki nilai Pearson's correlation yang lebih besar dari 0,30 sehingga seluruh indikator tersebut telah memenuhi syarat validitas data.

Uji reliabilitas dilakukan dengan melihat hasil dari Cronbach's Alpha Coefficient. Variabel dapat reliabel apabila nilai cronbach's alpha lebih besar dari 0,60. Nilai cronbach's alpha masing-masing variabel pada penelitian ini memiliki nilai lebih besar dari 0,60 . Hal ini menunjukkan bahwa semua pernyataan dalam kuesioner reliabel dan dapat digunakan. Hasil uji reliabilitas dapat dilihat pada Tabel 3. 
Tabel 3.

Hasil Uji Reliabilitas

\begin{tabular}{clrc}
\hline No & \multicolumn{1}{c}{ Variabel } & Cronbach's Alpha & Keterangan \\
\hline 1 & Kinerja Karyawan (Y) & 0,887 & Reliabel \\
2 & Efektivitas SIA (X1) & 0,835 & Reliabel \\
3 & Insentif (X2) & 0,802 & Reliabel \\
4 & Motivasi Kerja (X3) & 0,871 & Reliabel \\
\hline Sumber $:$ Data diolah, 2018
\end{tabular}

Informasi sebuah data yang dilihat dari jumlah sampel, nilai minimum, nilai maksimum, nilai rata-rata, dan standar deviasi dari masing-masing variabel penelitian didapatkan dari Analisis statistik deskriptif. Hasil statistik deskriptif pada penelitian ini dapat dilihat pada Tabel 4.

Tabel 4.

Hasil Analisis Statistik Deskriptif

\begin{tabular}{lccccc}
\hline \multicolumn{1}{c}{ Variabel } & N & Minimum & Maximum & Mean & $\begin{array}{c}\text { Std. } \\
\text { Deviation }\end{array}$ \\
\hline Efektivitas SIA (X1) & 99 & 16 & 30 & 24,46 & 3,740 \\
Insentif (X2) & 99 & 18 & 30 & 25,78 & 2,863 \\
Motivasi Kerja (X3) & 99 & 18 & 30 & 25,80 & 3,423 \\
Kinerja Karyawan (Y) & 99 & 18 & 30 & 26,03 & 3,234 \\
\hline
\end{tabular}

Sumber : Data diolah, 2018

Variabel efektivitas system informasi akuntansi mempunyai nilai minimum dan nilai maksimum masing-masing sebesar 16 dan 30 dengan rata-rata senilai 24,46 . Terdapat standar deviasi dalam variabel efektivitas sistem informasi akuntansi yaitu sebesar 3,740. Variabel insentif memiliki nilai minimum dan nilai maksimum masing-masing sebesar 18 dan 30 dengan nilai rata-rata sebesar 25,78. Standar deviasi pada variabel insentif adalah sebesar 2,863. Variabel motivasi kerja dengan nilai minimum sebesar 18 dan memiliki nilai maksimum sebesar 30 dengan nilai rata-rata sebesar 25,80. Standar deviasi pada variable insentif sebesar 3,423. Variabel kinerja karyawan memiliki nilai minimum sebesar 18 dan nilai maksimum sebesar 30 dengan nilai rata-rata sebesar 26,03 dan memiliki standar deviasi pada variabel insentif adalah sebesar 3,234. 
Untuk menguji data berdistribusi normal atau tidak dapat menggunakan uji normalitas, uji normalitas dilakukan untuk menguji apakah dalam model regresi, data residual mempunyai distribusi normal (Ghozali, 2016:160) melalui Uji Kolmogorov-Smirnov dengan kriteria normal apabila koefisien Asymp. Sig (2tailed) lebih besar dari tingkat alpha yaitu 0,05 (5\%). Hasil uji normalitas dapat dilihat pada Tabel 5 .

Tabel 5.

Hasil Uji Normalitas

\begin{tabular}{cc}
\hline Kolmogorov-Smirnov & Unstandardized Residual \\
\hline $\mathrm{N}$ & 99 \\
Asymp. Sig.(2-tailed) & 0,606 \\
\hline
\end{tabular}
Sumber: Data diolah, 2018

Berdasarkan Tabel 5 tersebut menunjukkan bahwa Asymp. Sig. (2-tailed) sebesar 0,606 lebih besar dari level of significant sebesar 0,05 sehingga dapat disimpulkan bahwa data terdistribusi secara normal.

Penelitian ini ingin menguji ada tidaknya korelasi pada variabel bebas dan variabel moderasi tanpa memasukkan interaksi antara variabel bebas dengan variabel moderasi. Pada model regresi yang baik seharusnya tidak terdapat korelasi diantara variabel terikat atau independen. Jika nilai tolerance lebih dari 10\% atau VIF kurang dari 10, maka dikatakan tidak ada multikolinearitas. Tabel 6 berikut menyajikan hasil uji multikolinearitas.

Tabel 6. Hasil Uji Multikolinearitas

\begin{tabular}{clcc}
\hline \multicolumn{1}{c}{ Variabel } & Tolerance & VIF \\
\hline 1 & Efektivitas SIA (X1) & 0,904 & 1,106 \\
2 & Insentif (X2) & 0,620 & 1,614 \\
3 & Motivasi Kerja (X3) & 0,658 & 1,521 \\
\hline
\end{tabular}

Sumber: Data diolah, 2018 
Pada Tabel 6 dapat dilihat bahwa nilai tolerance pada masing-masing variable bernilai diatas $0,1(10 \%)$ dan nilai VIF lebih kecil dari 10 , sehingga dijelaskan bahwa regresi pada model tersebut tidak terjadi multikolinearitas.

Untuk menguji adanya ketidaksamaan variance dapat menggunakan Uji heteroskedastisitas dari residual satu pengamatan ke pengamatan lainnya dengan menggunakan Uji Glejser. Model regresi yang baik adalah model regresi yang tidak mengandung heteroskedastisitas atau memiliki nilai signifikansi lebih besar dari $\alpha=0,05$ (5\%). Tabel 7 berikut menyajikan hasil uji heteroskedastisitas.

Tabel 7.

Hasil Uji Heteroskedastisitas

\begin{tabular}{lcc}
\hline \multicolumn{1}{c}{ Model } & Sig. & Keterangan \\
\hline Efektivitas SIA (X1) & 0,084 & Bebas heteroskedastisitas \\
Insentif (X2) & 0,305 & Bebas heteroskedastisitas \\
Motivasi Kerja (X3) & 0,231 & Bebas heteroskedastisitas \\
\hline Sus
\end{tabular}

Sumber : Data diolah, 2018

Tabel 7 dapat dilihat bahwa seluruh variabel memiliki nilai sig. lebih dari $\alpha=0,05$. Hal ini menunjukkan bahwa data dari variabel penelitian tidak mengandung gejala heteroskedastisitas.

Tabel 8 menyajikan analisis dari regresi linear sederhana digunakan untuk mengetahui pengaruh efektivitas sistem informasi akuntansi pada kinerja karyawan.

Tabel 8.

Hasil Analisis Regresi Linear Sederhana

\begin{tabular}{|c|c|c|c|c|c|}
\hline \multirow[b]{2}{*}{ Model } & \multicolumn{2}{|c|}{$\begin{array}{c}\text { Unstandardized } \\
\text { Coefficients }\end{array}$} & \multicolumn{2}{|c|}{$\begin{array}{c}\text { Standardized } \\
\text { Coefficients }\end{array}$} & \multirow[b]{2}{*}{ Sig. } \\
\hline & $\mathrm{B}$ & Std. Error & Beta & $\mathrm{t}$ & \\
\hline (Constant) & 13,721 & 1,767 & & 7,765 & 0,000 \\
\hline Efektivitas SIA (X1) & 0,503 & 0,071 & 0,582 & 7,046 & 0,000 \\
\hline
\end{tabular}

Sumber: Data diolah, 2018

Berdasarkan Tabel 8 dapat disusun persamaan regresi sebagai berikut:

$$
\mathrm{Y}=13,721+0,503 \mathrm{X} 1+\varepsilon
$$


Nilaikonstanta sebesar 13,721 menunjukkan bahwa apabila nilai efektivitas sistem informasi akuntansi sama dengan nol, makakinerja karyawan adalah sebesar 13,721 . Nilai koefisien $\beta_{1}=0,503$. Hal ini menunjukkan bahwa variabel efektivitas sistem informasi $\left(\mathrm{X}_{1}\right)$ mempunyai pengaruh positif terhadap kinerja karyawan (Y), bila efektivitas system informasi akuntansi meningkat satu satuan akan cenderung meningkatkan kinerja karyawan dengan asumsi variabel lainnya konstan.

Teknik analisis yang digunakan untuk memecahkan permasalahan penelitian ini adalah Moderated Regression Analysis (MRA) yang hasilnya tersaji pada Tabel 9 .

Tabel 9.

Hasil Analisis Regresi Moderasi

\begin{tabular}{|c|c|c|c|c|c|}
\hline \multirow[b]{2}{*}{ Model } & \multicolumn{2}{|c|}{$\begin{array}{c}\text { Unstandardized } \\
\text { Coefficients }\end{array}$} & \multicolumn{2}{|c|}{$\begin{array}{c}\text { Standardized } \\
\text { Coefficients }\end{array}$} & \multirow[b]{2}{*}{ Sig. } \\
\hline & $\mathrm{B}$ & Std. Error & Beta & $\mathrm{t}$ & \\
\hline (Constant) & $-15,241$ & 11,085 & & $-1,375$ & 0,172 \\
\hline Efektivitas SIA (X1) & 1,025 & 0,463 & 1,186 & 2,213 & 0,029 \\
\hline Insentif (X2) & 2,155 & 0,503 & 1,908 & 4,289 & 0,000 \\
\hline Motivasi Kerja (X3) & $-0,900$ & 0,416 & $-0,953$ & $-2,163$ & 0,033 \\
\hline $\mathrm{X} 1 \mathrm{X} 2$ & $-0,066$ & 0,021 & $-2,756$ & $-3,164$ & 0,002 \\
\hline $\mathrm{X} 1 \mathrm{X} 3$ & 0,040 & 0,017 & 1,732 & 2,342 & 0,021 \\
\hline
\end{tabular}

Berdasarkan Tabel 9 dapat disusun persamaan regresi sebagai berikut:

$$
\mathrm{Y}=-15,241+1,025 \mathrm{X} 1+2,155 \mathrm{X} 2-0,900 \mathrm{X} 3-0,066 \mathrm{X} 1 \mathrm{X} 2+0,040 \mathrm{X} 1 \mathrm{X} 3+\varepsilon
$$

Nilai konstanta sebesar -15,241 menunjukkan bahwa apabila nilai efektivitas sistem informasi akuntansi (X1), insentif (X2), dan motivasi kerja (X3) sama dengan nol, maka kinerja karyawan adalah sebesar -15,241. Nilai koefisien $\beta_{1}=1,025$. Hal ini menunjukkan bahwa variabel efektivitas sistem informasi $\left(\mathrm{X}_{1}\right)$ mempunyai pengaruh positif terhadap kinerja karyawan (Y), bila efektivitas 
sistem informasi akuntansi meningkat satu satuan akan cenderung meningkatkan kinerja karyawan dengan asumsi variabel lainnya konstan.

Nilai koefisien $\beta_{2}=2,155$. Hal ini menunjukkan bahwa variable insentif $\left(\mathrm{X}_{2}\right)$ mempunyai pengaruh positif terhadap kinerja karyawan $(\mathrm{Y})$, bila insentif meningkat satu satuan akan cenderung meningkatkan kinerja karyawan dengan asumsi variabel lainnya konstan. Nilai koefisien $\beta_{3}=-0,900$. Hal ini menunjukkan bahwa variabel motivasi kerja $\left(\mathrm{X}_{3}\right)$ mempunyai pengaruh negatif terhadap kinerja karyawan (Y), bila motivasi kerja meningkat satu satuan akan cenderung menurunkan kinerja karyawan dengan asumsi variable lainnya konstan.

Nilai koefisien $\beta_{4}=-0,066$. Hal ini menunjukkan bahwa interaksi efektivitas sistem informasiakuntansi dan insentif mempunyai pengaruh negatif terhadap kinerja karyawan. Apabila interaksi variabel efektivitas sistem informasi akuntansi dan insentif meningkat sebesar satu satuan maka variabel kinerja karyawan memiliki kecenderunganakan menurundengan asumsi variabel lain konstan. Nilai koefisien $\beta_{5}=0,040$. Hal ini menunjukkan bahwa interaksi variabel efektivitas sistem informasi akuntansi dan motivasi kerja mempunyai pengaruh positif terhadap kinerja karyawan. Apabila interaksi variabel efektivitas sistem informasi akuntansi dan motivasi kerja meningkat sebesar satu satuan maka variabel kinerja karyawan memiliki kecenderungan akan meningkat dengan asumsi variabel lain konstan.

Uji kelayakan model bertujuan untukmengetahui apakah model regresi penelitian ini layak digunakan untuk uji hipotesis. Bila nilai sig. dari $\mathrm{F} \leq \alpha$ sebesar 
0,05 (5\%), maka memenuhi syarat untuk uji kelayakan model.Tabel 10 berikut menunjukkan hasil dari uji kelayakan model (Uji F).

Tabel 10.

Hasil UjiKelayakan Model (Uji F)

\begin{tabular}{lrrrrr}
\hline Model & Sum of Squares & df & Mean Square & F & Sig. \\
\hline 1 Regression & 678,130 & 5 & 135,626 & 36,372 & 0,000 \\
Residual & 346,779 & 93 & 3,729 & & \\
Total & 1024,909 & 98 & & & \\
\hline
\end{tabular}

Sumber : Data diolah, 2018

Nilai uji signifikansi $\mathrm{F}$ atau p-value yang diperoleh sebesar 0,000 lebih kecil dari nilai $\alpha=0,05$. Hal ini berarti bahwa variabel efektivitas sistem informasi akuntansi (X1), insentif (X2), motivasi kerja (X3), interaksi X1X2, dan interasi X1X3 secara bersama-sama (simultan) berpengaruh pada kinerja karyawan (Y), sehingga model penelitian ini dikatakan layak untuk digunakan.

Uji t dilakukan dengan membandingkan nilai signifikansi yang dihasilkan dengan nilai $\alpha=0,05$. Hasil analisis data pada Tabel 8 menunjukkan bahwa variabel efektivitas sistem informasi akuntansi memiliki nilai $\beta_{1}$ positif lebih besar daripada nol sebesar 0,503 dengan tingkat signifikansi sebesar 0,000 yang lebih kecil daripada alpha $(0,05)$. Hal ini menunjukkan bahwa $\mathrm{H}_{1}$ diterima, yang mempunyai arti bahwa efektivitas system informasi akuntansi berpengaruh positif dan signifikan pada kinerja karyawan.

Hasil analisis data pada Tabel 9 menunjukkan bahwa interaksi efektivitas sistem informasi akuntansi dengan insentif memiliki nilai $\beta_{4}$ negatif lebih besar daripada nol sebesar -0,066 dengan tingkat signifikansi sebesar 0,002 yang lebih kecil daripada alpha (0,05). Hal ini menunjukkan bahwa $\mathrm{H}_{2}$ ditolak, yang mempunyai arti bahwa insentif memperlemah pengaruh efektivitas sistem informasi akuntansi pada kinerja karyawan. 
Hasil analisi pada tabel 9 menunjukkan bahwa interaksi efektivitas sistem informasi akuntansi dengan motivasi kerja memiliki nilai $\beta_{5}$ positif lebih besar daripada nol sebesar 0,040 dengan tingkat signifikansi sebesar 0,021 yang lebih kecil dari alpha $(0,05)$. Hal ini menunjukkan bahwa $\mathrm{H}_{3}$ diterima, yang mempunyai arti bahwa motivasi kerja mampu memperkuat pengaruh efektivitas sistem informasi akuntansi pada kinerja karyawan.

Uji koefisien determinasi $\left(\mathrm{R}^{2}\right)$ digunakan untuk mengukur kemampuan variabel bebas dalam menerangkan variasi dari variabel terikat. Tabel 11 dan Tabel 12 berikut menunjukkan hasil dari uji koefisien determinasi $\left(\mathrm{R}^{2}\right)$.

\section{Tabel 11.}

\section{Hasil UjiKoefisien Determinasi $\left(\mathbf{R}^{2}\right)$ (Regresi Linear Sederhana)}

\begin{tabular}{ccccc}
\hline Model & $\mathrm{R}$ & R Square & Adjusted R Square & $\begin{array}{c}\text { Std. Error of the } \\
\text { Estimate }\end{array}$ \\
\hline 1 & 0,582 & 0,339 & 0,332 & 2,644 \\
\hline
\end{tabular}

Sumber : Data diolah, 2018

Tabel 11 menunjukkan bahwa nilai Adjusted $\mathrm{R}^{2}$ sebesar 0,332 yang berarti bahwa 33,2\% variasi kinerja karyawan dipengaruhi oleh variabel efektivitas sistem informasi akuntansi dan sisanya sebesar $66,8 \%$ dipengaruhi oleh faktor lain di luar model penelitian.

Tabel 12.

Hasil Uji Koefisien Determinasi ( $\left.\mathbf{R}^{2}\right)$ (MRA)

\begin{tabular}{ccccc}
\hline Model & $\mathrm{R}$ & $\mathrm{R}$ Square & Adjusted R Square & $\begin{array}{c}\text { Std. Error of } \\
\text { the Estimate }\end{array}$ \\
\hline 1 & 0,813 & 0,662 & 0,643 & 1,931 \\
\hline Sumber : Data diolah, 2018 & & &
\end{tabular}

Tabel 12 menunjukkan bahwa nilai Adjusted $\mathrm{R}^{2}$ sebesar 0,643 yang berarti bahwa $64,3 \%$ variasi kinerja karyawan dipengaruhi oleh variabel efektivitas sistem informasi akuntansi, insentif, motivasi kerja, interaksi antara efektivitas sistem informasi akuntanusi dengan insentif, dan interaksi antara 
efektivitas sistem informasi akuntansi dengan motivasi kerja, sedangkan 35,7\% sisanya dipengaruhi oleh faktor lain di luar model penelitian. BerdasarkanTabel 11 dan Tabel 12 dapat dilihat bahwa hasil uji koefisien determinasi $\left(\mathrm{R}^{2}\right)$ dari hasil uji analisis regresi linear sederhana lebih kecil daripada hasil uji regresi moderasi. Masuknya variable moderasi dan interaksi antara variable moderasi danvariabel bebas telah menyebabkan kenaikan pada koefisiendetermiasi $\left(\mathrm{R}^{2}\right)$. Hal ini mengindikasikan bahwa moderasi telah berhasil.

Hasil pengujian menunjukkan bahwa efektivitas system informasi akuntansi secara statistik berpengaruhpositif pada kinerja karyawan $\left(\mathrm{H}_{1}\right.$ diterima). Haltersebut berarti bahwa semakin efektif system informasi akuntansi yang dimiliki LPD makaakan semakin baikpula kinerja dari karyawan tersebut. Sistem informasi akuntansi yang efektif dapat memudahkan dan mempercepat penyelesaian tugas yang dilakukan setiap karyawan. Penggunaan system informasi akuntansi denganbaik maka akan memberikan manfaat bagi karyawan LPD dalam meningkatkan kinerjanya. Penelitian ini didukung oleh teori Technology to Performance Chain (TPC) yang menjelaskan bahwa sebuah teknologi akan berdampak terhadap kinerja sesuai dengan kemampuan individu pemakai teknologi tersebut. Sebuah sistem informasi akuntansi harus digunakan dan sesuai dengan tugas seseorang dan didukung oleh teknologi yang baik sehingga sistem informasi akuntansi dapat berjalan secara efektif dan mampu mendapatkan kinerja yang baik.

Hasil penelitian inisejalan dengan hasil penelitian yang dilakukan oleh Astuti \& Dharmadiaksa (2014), Antasari \& Yaniartha (2015), Gunawan \& Tenaya 
(2017), dan Sridarmaningrum \& Sari (2018) menyatakan bahwa efektivitas penerapan sistem informasi akuntansi secara parsial mempunyai pengaruh positif signifikan terhadap kinerja karyawan.

Hasil pengujian menunjukkan bahwa insentif mampu memoderasi efektivitas sistem informasi akuntansi pada kinerja karyawan namun dengan arah negatif. Hasil ini menolak hipotesis $2\left(\mathrm{H}_{2}\right)$ dan menyatakan bahwa insentif memperlemah pengaruh efektivitas sistem informasi akuntansi pada kinerja karyawan, dengan kata lain meningkatnya insentif tidakmampu meningkatkan pengaruh efektivitas system informasi akuntansi terhadap kinerja karyawan.

LPD dengan struktur penggajian dengan insentif tinggi sering kali diasosiasikan dengan kinerja yang tinggi, terlepas dari efektif tidaknya sistem informasi yang ada. Hal ini dapat diartikan bahwa efektivitas sistem informasi akuntansi tidak dominan pengaruhnya terhadap kinerja karyawan. Hasil penelitian ini mendukung teori ekspektansi yang menyatakan bahwa agar seorang karyawan dapat melaksanakan pekerjaannya menjadi lebih baik tergantung dari hubungan timbal balik yang diperoleh dari hasil pekerjaannya. Karyawan cenderung berusaha mempertahankan level kinerjanya karena kinerja berkaitan langsung dengan insentif yang akan diterima oleh karyawan tersebut. Namun sebaliknya, apabila struktur penggajian dengan insentif rendah maka tidak terdapat dorongan untuk meningkatkan pengaruh efektivitas sistem informasi akuntansi terhadap kinerja. Sehingga, apabila dalam suatu sistem informasi terjadi suatu gangguan atau rendahnya tingkat efektivitas sistem informasi akuntansi maka kinerja karyawan tersebut juga akan semakin rendah. 
Hasil pengujian menunjukkan bahwa motivasi kerja mampu memoderasi efektivitas sistem informasi akuntansi pada kinerja karyawan. Hasil inimenerima hipotesis $3\left(\mathrm{H}_{3}\right)$ yang menyatakan bahwa motivasi kerja memperkuat pengaruh efektivitas sistem informasi akuntansi pada kinerja karyawan. Hal ini mengindikasikan semakin tinggi motivasi kerja seseorang maka akan meningkatkan efektivitas system informasi akuntansi sehingga kinerja karyawan akan meningkat.

Penggunaan sistem informasi akuntansi yang efektif oleh seorang karyawan dan disertai motivasi kerja yang tinggi maka akan menghasilkan kinerja yang lebih baik. Ketika pemakai sistem informasi akuntansi yang efektif memiliki semangat dan dorongan kerja yang tinggi dalam bekerja maka kinerja karyawan dapat dinilai baik sehingga dapat terpenuhinya tujuan suatu perusahaan. Sebaliknya, apabila penggunaan sistem informasi akuntansi yang efektif tidak disertai dengan motivasi kerja yang tinggi maka kinerja karyawan akan menjadi tidak optimal. Tanpa adanya pemberian dorongan kepada karyawan untuk memicu munculnya motivasi kerja yang tinggi, maka karyawan akan cenderung tidak bersemangat dalam bekerja terutama dalam penggunaan sistem informasi akuntansi, sehingga seefektif apapun sistem tersebut tidak akan terlalu berpengaruh pada kinerja karyawan.

Penelitian ini didukung oleh teori Technology to Performance Chain (TPC) dan teori ekspektansi, dimana teori TPC mengasumsikan bahwa sebuah teknologi akan berdampak terhadap kinerja sesuai dengan kemampuan individu pemakai teknologi tersebut. Suatu teknologi mempunyai dampak positif pada 
kinerja individual karena dengan adanya teknologi akan sangat mendukung bagi penyelesaian tugas setiap individu dan berdampak pada kinerja yang dihasilkan. Teori ekspektansi yang menyatakan bahwa agar seorang karyawan dapat melaksanakan pekerjaannya menjadi lebih baik tergantung dari hubungan timbal balik yang diperoleh dari hasil pekerjaannya.

Penelitian ini diharapkan dapat menjadi pertimbangan bagi Lembaga Perkreditan Desa di Kota Denpasar agar tetap memperhatikan kinerja karyawannya. Penelitian ini menjelaskan bahwa teknologi sistem informasi telah berkembang dengan memanfaatkan teknologi informasi yang ada maka bisa tercipta solusi yang akan mempermudah LPD dan perusahaan perbankan lainnya dalam penggunaan sistem terkomputerisasi untuk mengerjakan tugasnya guna meningkatkan kesejahteraan masyarakat maupun lembaga terkait. Penggunaan sistem dengan baik akan meningkatkan kinerja karyawan LPD. Motivasi kerja yang tinggi dalam penggunaan sistem informasi akuntansi merupakan faktor yang dapat meningkatkan kinerja karyawan sehingga dapat menciptakan kinerja LPD menjadi lebih baik.

\section{SIMPULAN}

Menurut penelitian yang telah dilakukan adanya pengaruh positif dari efektivitas sistem informasi akuntansi terhadap kinerja karyawan di Lembaga Perkreditan Desa di Kota Denpasar. Hal tersebut menandakan semakin tinggi efektivitas sistem informasi akuntansi, maka kinerja karyawan akan semakin meningkatkan kinerja karyawan. 
Insentif memperlemah pengaruh efektivitas informasi akuntansi terhadap kinerja karyawan di Lembaga Perkreditan Desa di Kota Denpasar. Hal ini berarti bahwa semakin tinggi insentif yang diberikan maka tidak akan meningkatkan pengaruh efektivitas sistem informasi akuntansi pada kinerja karyawan.

Motivasi kerja memperkuat pengaruh efektivitas sistem informasi akuntansi terhadap kinerja karyawan di Lembaga Perkreditan Desa di Kota Denpasar. Hal ini berarti bahwa semakin tinggi motivasi kerja seseorang dalam penggunakan sistem informasi akuntansi maka akan meningkatkan kinerja karyawan tersebut.

Bagi LPD di Kota Denpasar, disarankan agar tetap memperhatikan dan mempertahankan keefektivitasan penggunaan sistem informasi akuntansi yang ada sehingga dapat dimanfaatkan sebaik mungkin untuk meningkatkan kinerja karyawan. Perusahaan juga disarankan untuk memberikan motivasi serta dorongan yang tinggi seperti penghargaan atas prestasi kerja yang dimiliki kepada masing-masing karyawan agar memberikan hasil kerja yang baik dalam penggunaan sistem informasi akuntansi.

Sangat disarankan untuk penelitian selanjutnya, menggunakan variabel moderasi lainnya seperti tingkat pendidikan dikarenakan berdasarkan data yang diperoleh pada peneltian diatas tingkat pendidikan paling banyak di LPD Kota Denpasar yaitu SMA/SMK. Peneliti selanjutnya juga disarankan untuk melakukan wawancara kepada karyawan LPD dalam metode pengumpulan data guna memperkuat hasil dari penelitian. Disarankan pula untuk memperluas cakupan wilayah penelitian, tidak terfokus pada Lembaga Perkreditan Desa saja melainkan 
bisa dilakukan penelitian di bidang lainnya atau perusahaan lainnya yang berbeda supaya lebih mampu melakukan generalisasi pada hasil penelitian.

\section{REFERENSI}

Al-Eqab, M., \& Adel, D. (2013). The Impact of IT Sophistications on the Perceived Usefulness of Accounting Information Characteristics among Jordanian Listed Companies. International Journal of Business and Social Science, 4(3), 145-155.

Ali, A., Abrar, M., \& Haider, J. (2012). Impact of Motivation on The Working Performance of Employees-A case Study of Pakistan. Global Advanced Research Journal of Management and Business Studies, 1(4), 126-133. Retrieved from http://garj.org/garjmbs/index.htm

Anggriawan, K. H., Hamid, D., \& Mukzam, M. D. (2015). Pengaruh Insentif dan Motivasi Terhadap Kinerja Karyawan ( Studi Pada Karyawan Cv Suka Alam ( Kaliwatu Rafting ) Kota Batu , Jawa Timur ). Jurnal Administrasi Bisnis $(J A B), 28(1), 50-55$.

Antasari, K. C., \& Yaniartha, P. D. S. (2015). Pengaruh Efektivitas Sistem Informasi Akuntansi dan Penggunaan Teknologi Informasi pada Kinerja Individual dengan Kepuasan Kerja sebagai Variabel Pemoderasi. E- Jurnal Akuntansi Universitas Udayana, 10(2), 354-369.

Ariputra, I. W. K., \& Suaryana, I. G. N. A. (2018). Budaya Organisasi Memoderasi Pengaruh Efektivitas Penerapan SIA dan Kesesuaian Tugas dengan TI terhadap Kinerja Karyawan. E- Jurnal Akuntansi Universitas Udayana, 22(1), 216-244. https://doi.org/https://doi.org/10.24843/EJA.2018.v22.i01.p09

Astuti, N. M. M. P., \& Dharmadiaksa, I. B. (2014). Pengaruh Efektivitas Penerapan Sistem Informasi Akuntansi, Pemanfaatan dan Kesesuaian Tugas pada Kinerja Karyawan. E- Jurnal Akuntansi Universitas Udayana, 9(2), 373-384.

BeritaBali. (2016). Walikota Denpasar Minta LPD Terus Ikuti Perkembangan Zaman. Retrieved October 29, 2018, from https://www.beritabali.com/read/2016/05/18/201605180005/WalikotaDenpasar-Minta-LPD-Terus-Ikuti-Perkembangan-Zaman.html

Bodnar, G. H., \& Hopwood, W. S. (2006). Sistem Informasi Akuntansi (9th ed.). Yogyakarta: ANDI. 
Dewi, I. G. A. L. P. (2014). Pengaruh Gaya Kepemimpinan Transformasional, Motivasi Kerja, dan Independensi Auditor Pada Kinerja Auditor Kantor Akuntan Publik Di Provinsi Bali. E-Jurnal Akuntansi Universitas Udayana.

Dwijayanthi, D. M., \& Dharmadiaksa, I. B. (2013). Pengaruh Insentif, Tingkat Pendidikan, Pelatihan Dan Pengalaman Kerja Terhadap Kinerja Individu Pengguna Sistem Informasi Akuntansi SKPD DISPENDA Kota Denpasar. E-Jurnal Akuntansi Universitas Udayana, 4(2), 332-344. https://doi.org/10.1095/biolreprod.110.085282

Fatmayoni, G., \& Yadnyana, K. (2017). Pengaruh Efektivitas SIA dan Penggunaan Teknologi Informasi pada Kinerja Individual dengan Insentif Karyawan sebagai Pemoderasi. E-Jurnal Akuntansi Universitas Udayana, 19(3), 2175-2204.

Ghaffari, S., Shah, I., Burgoyne, J., Nazri, M., \& Salleh, J. (2017). The Influence of Motivation on Job Performance: A Case Study at Universiti Teknologi Malaysia. Australian Journal of Basic and Applied Sciences, 11(4), 92-99.

Ghozali, I. (2016). Aplikasi Analisis Multivariat dengan Program IBM SPSS 23 (8th ed.). Semarang: Universitas Diponegoro.

Goodhue, D. L., \& Thompson, R. L. (1995). Task-Technology Fit and Individual Performance. MIS Quarterly, 19(2), 213-236. https://doi.org/10.1074/jbc.M110.194316

Gunawan, I. M. P. A., \& Tenaya, A. I. (2017). Pengaruh Efektivitas Sistem Informasi Akuntansi pada Kinerja Individual dengan Kemampuan Teknik Personal sebagai Pemoderasi. E- Jurnal Akuntansi Universitas Udayana, 20(2), 1621-1647.

Kharuddin, S., Ashhari, Z. M., \& Nassir, A. M. (2010). Information System and Firms' Performance: The Case of Malaysian Small Medium Enterprises. International Business Research, 3(4), 28-35.

Kouser, R., Awan, A., \& Shahzad, F. (2011). Firm Size, Leverage and Profitability: Overriding Impact of Accounting Information System. Business \& Management Review, 1(10), 58-64. Retrieved from http://search.ebscohost.com/login.aspx?direct=true\&profile=ehost\&scope=sit e\&authtype $=$ crawler \&jrnl=20470398\&AN=78392126\&h=LdLODNIDaSzC P\%2BA7P8QsaL45dyKOJAL4z971EkgKxJeXW70QWzSCJkKL3XuyAOm 3Yp0DG6KYFdds9dNjewpP0w\%3D\%3D\&crl=c

Krisnawati, N. P. A., \& Suartana, I. W. (2017). Pengaruh Kompetensi Karyawan , Motivasi Kerja , Komitmen Organisasi , Kemampuan Teknik Personal 
Terhadap Kinerja Sistem Informasi Akuntansi. E- Jurnal Akuntansi Universitas Udayana, 21(3), 2539-2566. https://doi.org/https://doi.org/10.24843/EJA.2017.v21.i03.p30

Kristiani, W. (2012). Analisis Pengaruh Efektivitas Teknologi Sistem Informasi Akuntansi terhadap Kinerja Individual Pegawai PT. Kim Eng Sekuritas Indonesia. Jurnal Fakultas Ekonomi Universitas Gunadarma.

Mahardhika, R., Hamid, D., \& Ika, R. (2013). Pengaruh Motivasi Kerja Terhadap kinerja Karyawan (Survei Karyawan Pada PT. Axa Financial Indonesia Sales Office Malang). Jurnal Administrasi Bisnis (JAB), 4(2), 1-10.

Mercika, N. L. D. T., \& Jati, I. K. (2015). Kemudahan Penggunaan Sistem sebagai Pemoderasi Pengaruh Efektivitas Sistem Informasi Akuntansi pada Kinerja. E- Jurnal Akuntansi Universitas Udayana, 10(3), 723-737.

Novita, H. (2011). Efektivitas Sistem Informasi Akuntansi Dampaknya terhadap Kinerja Karyawan pada PT.Dwi Daya Sentra Prakasa (PERSERO). Jurnal Fakultas Teknik Dan Ilmu Komputer Universitas Komputer Indonesia.

Nwokeji, E. N. A. (2012). Repositioning Accounting Information System Through Effective Data Quality Management: A Framework for Reducing Costs and Improving Performance. International Journal of Scientific \& Technology Research, 1(10), 86-94.

Rai, A., Lang, S. S., \& Welker, R. B. (2002). Assessing the Validity of IS Success Models: An Empirical Test and Theoretical Analysis. Information Systems Research, 13(1), 50-113. https://doi.org/10.1287/isre.13.1.50.96

Sandi, E. P. (2014). Kejari Lanjutkan Penyelidikan LPD Serangan. Retrieved November 4, 2018, from http://bali.tribunnews.com/2014/08/23/kejarilanjutkan-penyidikkan-lpd-serangan

Soudani, S. N. (2012). The Usefulness of an Accounting Information System for Effective Organizational Performance. International Journal of Economics and Finance, 4(5), 136-145. https://doi.org/10.5539/ijef.v4n5p136

Sridarmaningrum, L. G., \& Sari, W. N. L. (2018). Pengaruh Efektivitas Sistem Informasi Akuntansi, Kesesuaian Tugas, Kenyamanan Fisik dan Lingkungan Kerja pada Kinerja Karyawan. E- Jurnal Akuntansi Universitas Udayana, 23(3), 1955-1979. https://doi.org/https://doi.org/10.24843/EJA.2018.v23.i03.p13

Sugiartini, N. M., \& Dharmadiaksa, I. B. (2016). Pengaruh Efektivitas Teknologi Sistem Informasi Akuntansi pada Kinerja Individu dengan Budaya Organisasi sebagai Pemoderasi. E-Jurnal Akuntansi Universitas Udayana, 
14(3), 1867-1894.

Surbakti, R. T. (2014). Pengaruh Motivasi Kerja terhadap Kinerja Karyawan Golongan 1 di Universitas Katolik Parahyangan. E-Journal Graduate Unpar, $1(2), 211-232$.

Suryawan, I. K. S., \& Suaryana, I. G. N. A. (2018). Pengaruh Efektivitas Sistem Informasi Akuntansi Terhadap Kinerja Individual dengan Insentif sebagai Variabel Pemoderasi Pada LPD. E- Jurnal Akuntansi Universitas Udayana, 23(2), 871-897.

Urquia, E., Perez, R., \& Munoz, C. (2011). The Impact of Accounting Information Systems ( AIS ) on Performance Measures. The International Journal of Digital Accounting Research, 11(February), 25-43. https://doi.org/10.4192/1577-8517-v11

Verbeeten, F. H. M. (2008). Performance management practices in public sector organizations: Impact on performance. Accounting, Auditing and Accountability Journal, 21(3), 427-454. https://doi.org/10.1108/09513570810863996

Veriana, P. A. A., \& Budiartha, I. K. (2016). Pengaruh Efektivitas Penerapan Sistem Informasi Akuntansi, Budaya Organisasi, dan Kesesuaian Tugas pada Kinerja Karyawan. E- Jurnal Akuntansi Universitas Udayana, 17(3), 22252252.

Widyastuti, P. and, \& Hasan, F. (2015). Pengaruh Budaya Organisasi dan Pengalaman Kerja terhadap Kinerja Karyawan dengan Motivasi Kerja sebagai Moderating pada Koperasi Pegawai PLN Sektor Priok. Journal.Uta45jakarta, 1-14. 